
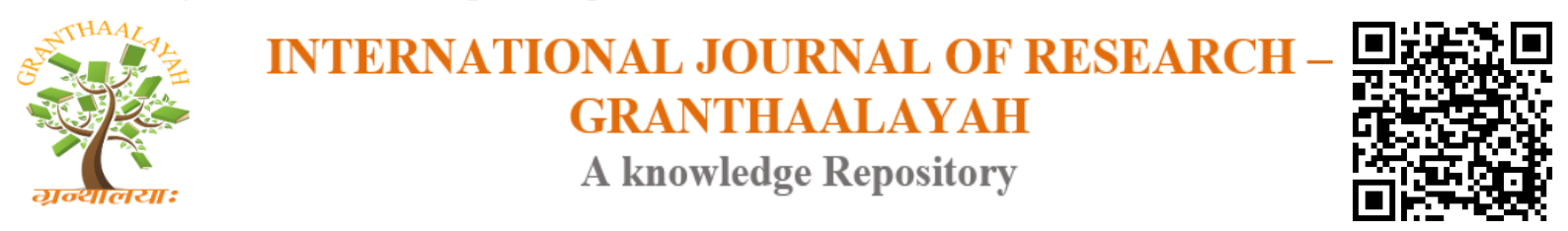

Social

\title{
MODEL OF THE FORMATION OF RESEARCH COMPETENCE OF STUDENTS-MATHEMATICIANS OF A PEDAGOGICAL UNIVERSITY
}

\author{
Kaskatayeva Bakhytkul *1 \\ ${ }^{* 1}$ Doctor of Pedagogy, Associate Professor, Kazakh State Women's Teacher Training University \\ (KazMKPU), Kazakhstan
}

\begin{abstract}
In this article, a model is developed for the formation of the research competence of undergraduate mathematicians at a pedagogical university. Purposeful formation of research competence in the conditions of digitalization, development of theoretical approaches to the use of ICT tools in order to: develop the trainee's personality by involving the trainee in experimental research, forming cognitive interest is one of the most important goals of higher pedagogical education. The purpose of the study is to develop a model for the formation of research competence of studentsmathematicians of a pedagogical university, including the forms, means and methods of its formation; The research uses research methods as a theoretical analysis of domestic and foreign scientific literature on the research problem; observation, generalization; As a result, we determined the essence of research competence and developed a model for the formation of research competence (IC) of mathematics students of a pedagogical university, including the forms, means and methods of its formation; To effectively implement the model for the formation of the research competence of the future mathematics teacher, pedagogical conditions have been created that are of great importance for the formation of the research competence of the mathematics teacher. Formation of the IC was conducted through psychological, informativecognitive, practical training.
\end{abstract}

Keywords: Model; Research Competence; Forms; Means and Methods; Pedagogical University.

Cite This Article: Kaskatayeva Bakhytkul. (2018). "MODEL OF THE FORMATION OF RESEARCH COMPETENCE OF STUDENTS-MATHEMATICIANS OF A PEDAGOGICAL UNIVERSITY." International Journal of Research - Granthaalayah, 6(9), 53-71. https://doi.org/10.5281/zenodo.1435223.

\section{Introduction}

The main objective of educational programs in a pedagogical university is to deepen specialization in a certain professional direction. Education in a pedagogical university is an important stage in the formation of a professional researcher, a step leading a young scientist to a project, thesis and dissertational research. That is why research work is of great importance for students enrolled in bachelor's and master's programs at a pedagogical university. 
At present, the issues of the formation of research competence (IR) of students are actively researched by scientists. However, the existing educational practice does not promote the maximum stimulation of the research orientation of the pedagogical work of the future specialist, which makes it necessary to study the theoretical aspects of such a phenomenon as the "research competence" of the future teacher and the methods of its formation. In order to reveal the essence of the term "research competence" it was necessary to study such concepts as "competence", "competence" and "research".

Research in the broadest sense - the search for new knowledge or a systematic investigation to establish facts. In a narrower sense, research is a scientific method (process) of studying something. Scientific research, based on the application of the scientific method, provides scientific information and theories to explain the nature and properties of the surrounding world. Such a study may have practical application [30].

The relevance of the research on the scientific and theoretical level is determined by the materials of UNESCO [24], the Law of the RK "On Education" [25], the Concept of the State Youth Policy of the Republic of Kazakhstan until 2020 "Kazakhstan 2020: the way to the future" [26], the State Educational Standard [23] ] and scientific research, in which the expected result of modern education, based on a competence approach, are constructs from universal and professional competences. Of great importance in this regard are the works of the scientists I.S. Sergeeva [20], V.I. Bidenko [2], A.A. Verbitsky [29], I.A. Winter [32], G.I. Ibragimov [9], A.V. Khutorskogo [4], and psychological and pedagogical studies of VS. Elagina [7], A.M. Derkach [6], G.N. Lobova [15], revealing the main points of the competence approach.

To the interpretation of the concept of "research competence" there are different approaches. Let's dwell on some of them. Research competence from the position of the knowledge-operational approach (MA Danilov, EF Sezer, M.A. Choshanov and others) is defined as the totality of knowledge and skills necessary for carrying out research activities [5, 31, 3];

Research competence manifests itself in theoretical literacy, possession of methods of psychological and pedagogical research, the ability to statistically process empirical data, formulate conclusions, and present the results of research. "Research competence" from the viewpoint of the procedural and technological approach (A.V. Khutorskaya) is regarded as the possession of a person with the relevant research competence, which should be understood as knowledge as a result of the cognitive activity of a person in a certain field of science, methods, research methods that he must master, to carry out research activities, as well as the motivation and position of the researcher, his value orientations [4; 327]. The concept of "research competence" - from the position of the functional-activity approach (N.V. Kuzmina, A.K. Markov, V.D. Shadrikov, etc.) is considered as a set of personal qualities necessary for effective research activities [13, 17, 21]. V.D. Shadrikov defines "competence as a systemic manifestation of knowledge, skills, abilities, and personal qualities. Research competence from the position of the system approach (LA Golub, VS Lazarev, etc.) is considered as a component of professional competence [8, 14]. In our study, based on a systematic approach, we consider the research competence of the teacher as the main component of professional competence. 
VA Slastenin emphasizes that the structural components of research competence must coincide with the components of research activity, and the unity of theoretical and practical research skills constitute a model of students' research competence [22, p. 83]. Research competence is the key, the basis for the development of other more specific and subject-oriented competencies, since it helps the student to learn, allows him to become more flexible, competitive, helps to be more successful in later life, which determines the significance of its formation.

In connection with the reform in the education system, it becomes necessary to create a model for the formation of the research competence of undergraduate mathematicians at a pedagogical university. Before the higher school the task is set to raise a new generation of professionally competent teachers in accordance with the modern model of RK education under conditions of digitalization [27].

To date, there has been insufficiently developed a methodology for developing the research competence of mathematical students. In this connection, there arises the need to develop a model for the formation of research competence of students-mathematicians of a pedagogical university, including the forms, means and methods of its formation, which predetermined the relevance of this topic.

The subject of the study is the professional preparation of students for research activities The purpose of the research: the development of a model for the formation of research competence of students-mathematicians of a pedagogical university, including the forms, means and methods of its formation.

Research hypothesis: if the model of forming the research competence of studentsmathematicians of a pedagogical university, including the forms, means and methods of its formation will be applied in the preparation of future mathematics teachers, it will increase the readiness of the future mathematics teacher to professional activity.

Research methods: theoretical analysis of domestic and foreign scientific literature on the research problem; observation, generalization;

\section{Materials and Methods}

Determining effective ways of training future educators in the Republic of Kazakhstan, creating a national model of the education system is the most important and complex issue. "At the moment, we have begun to raise the economy, the social sphere, ... it's time to pay attention to the problems of education. It is here, ... it is necessary to complete the reform of secondary and higher education" [12]. The development of the education system in our country since the day of gaining independence is mainly conducted in two directions. They are: 1) the preservation of all the positive results accumulated during the years of Soviet power; 2) the search for ways to create a new model of the Kazakhstani education system, taking into account the prevailing political, economic, social conditions.

"Vocational training is the process of acquiring the skills that are necessary for the performance of certain duties related to work or a group of works" [1]. The main components of the teacher's professionalism, his pedagogical skills are professional competence, creativity, culture, 
technology, individual style, innovative and research approach to activities, and its productivity. The higher stage of professional competence is manifested in a teacher with experience, but the prerequisites for it and individual components are formed during the period of education in a pedagogical college [28].

The professional competence of the teacher is a multifactorial phenomenon that includes the system of theoretical knowledge of the teacher and the ways of using them in specific pedagogical situations, the teacher's value orientations, as well as integrative indicators of his culture (speech, communication, attitude to himself and his activities, to related fields knowledge, etc.).

By professional competence is understood the totality of professional and personal qualities necessary for successful pedagogical activity. Professional competent can be called a teacher who at a sufficiently high level carries out pedagogical activity, pedagogical communication, achieves consistently high results in development and upbringing [19].

The final milestone in the professional training of future specialists is the formation of their professional competence. The research competence of the teacher, as we see, is a component of professional competence, and ensures its effectiveness.

Research competence is a characteristic of a teacher's personality, who possess professional knowledge, skills and research methods, perseverance in search work until a scientific result is obtained.

We conducted an analysis of the psychological and pedagogical scientific literature of the concept and its content, the theoretical foundations of the formation of research competence in the professional training of the teacher of mathematics.

In the study of research competence, we relied on the theoretical basis of professional competence. Since it is the main component of professional competence.

As a result of the analysis and study of the works of scientists devoted to research, we defined the term "research competence" as "an integral, integral characteristic of the personality of the future teacher of mathematics, manifested in his willingness to take an active creative research position in relation to educational mathematical activity and enabling the obtaining of the best research results "[10]. Earlier we have defined pedagogical conditions of formation of research competence of graduates - teachers of mathematics of pedagogical University [11].

One of the most important directions in the formation of research competence of students in the conditions of a higher school is properly organized research activity. Its organization and implementation in the university's teaching process is one of the main conditions for achieving a high level of research competence.

The essence of research competence of students is manifested through the interrelation of its main components: value-motivational, cognitive-active, communicative. 
The value-motivational component is determined by: the presence of interest in research activities and vocational education; understanding of the importance of research work in life and the importance of studying the disciplines studied in the development of students' research qualities; the focus on achieving its results;

The cognitive-activity component is represented by the students' abilities to use the acquired knowledge in various non-standard life situations; the development of students' self-organization, self-reliance, self-learning and self-development. And also the possession of a system of knowledge about research activities, its norms and values in modern society.

The communicative component is determined by the skills of students to extract and process information, skills to work with modern computer, multimedia and other equipment; the ability to find and see non-standard ways of solving problems; willingness to represent the results of his research work and the ability to work in a team with mutual understanding. Thus, research competence consists of three components: value-motivational, cognitive-active, communicative. From the above definition of "research competence of the future teacher of mathematics" and on the basis of the model of vocational training of the teacher of mathematics, G.L. Lukankin, we posed the question of creating a model for the formation of the research competence of the future teacher of mathematics.

The vocational training model of GL Lukankin [16] consists of three blocks:

- formation of the personality of the citizen-teacher;

- the formation of a teacher-teacher;

- the formation of a competent specialist - the teacher of the subject.

The composition of competence is as follows:

1) the methodological focus of training;

2) the professional-pedagogical orientation of socio-political disciplines;

3) the vocational and subject orientation of psychological and pedagogical training;

4) the professional orientation of mathematical training;

5) the scientific-theoretical and practical orientation of research training;

6) increase the scientific-theoretical and scientific-research level of continuous pedagogical practice of students;

7) realization of the personality-activity approach in the training of specialists;

8) arming future specialists with new pedagogical and information technologies;

9) implementation of continuous computer training of teachers;

10) development of educational-scientific-industrial-pedagogical complex [16, c.59].

To create a meaningful model for the formation of the research competence of the teacher, it was first of all necessary to consider the following issues:

- Definition of pedagogical conditions for the formation of research competence in the system of teacher education;

- Creation of a model for the formation of the research competence of the mathematics teacher and its implementation in vocational training;

- Definition of the characteristics of a competent teacher of mathematics (model building). 
Formation of research competence in the professional training of the future teacher is fruitfully carried out with the help of psychological, informative-cognitive, practical readiness, which are an integral part of the professional preparation of the future teacher. The significance of the model of the process of forming research competence is to increase the importance of mastering the methodology of research activities and the formation of personal cognitive qualities and the creation of individual experience on the basis of continuous pedagogical practice. It consists of three stages: psychological, content-cognitive, practical. At the stage of psychological preparation, motivation is directed toward cognitive activity, during which pedagogical, psychological, and mathematical knowledge is mastered; formation of personal-professional, cultural, motivational, reflective qualities, stimulation to research work. For this, a motivational-cognitive and valuable meaningful choice is carried out.

At the stage of content-cognitive training, scientific bases for the realization of the subjective direction of the student as a teacher are created. For this, an exchange of views, self-knowledge, search, critical analysis of information is used. Didactic and educational-research skills are formed, as well as the ability to use the acquired knowledge in various non-standard life situations; is conditioned by the system of knowledge about research activity, its norms and values in modern society.

At the stage of practical preparation of students, students are replenished and updated with new forms and methods of forming all three components of research competence: value-motivational, cognitive-activity, communicative competence. Students are given guidance on professional selfimprovement. During the pedagogical practice, the following is observed:

1) for the educational process;

2) for research activities of students;

3) for the organization and independent fulfillment of creative research projects of students with the purpose of forming their research skills.

\section{Results and Discussions}

Thus, the research competence of the future teacher of mathematics is determined, consisting of the value-motivational, cognitive-activity, communicative components and their full description is given.

On the basis of scientific analysis and diagnostics, the structure of research competence is determined and a model is developed that shows a holistic picture of the formation of research competence, which includes these components (figure-1). In the process of forming the research competence of the future mathematics teacher on the proposed model, the following work with students should be conducted:

1) to provide a quality education with the use of modern innovative methods, tools and technologies;

2) stimulation of research activities, personal development and development of new technologies; mastering the methods of pedagogical diagnostics;

3) forming the skills of professional self-improvement;

4) train the abilities for professional-research activities; 
5) organize and observe the development of the pedagogy of mathematics, psychology, mathematics and new teaching technologies;

6) be able to put forward hypotheses, justify them; to see and isolate problems, to cost assumptions about their resolution, to be able to set a task, to reveal in it its conditions;

7) the formation of research competence of students in connection with the research capabilities of the content of mathematics itself;

The emergence of components of research competence is due to the fact that its properties are formed as part of a unified system.

In pedagogical universities the model of the formation of the research competence of the teacher of mathematics in their professional training was conducted through psychological training; informative-cognitive; practical training.

The model of the formation of the IR includes: the purpose, objectives, principles, content of training, methods, tools, methodologies and technologies.

The study specifies the pedagogical conditions necessary for the formation of research competence; the principles of forming the research competence of the mathematics teacher are defined; criteria are determined reflecting the level of the development of research competence Specific features of the phased development of the properties of the research competence of the future teacher are determined. At the first stage of preparation of students in higher pedagogical educational institutions for the future profession of the teacher of mathematics, didactic methods and means of formation of infrared radiation are considered. In the process of formation of qualities, depending on the complexity of the issue, changes were made.

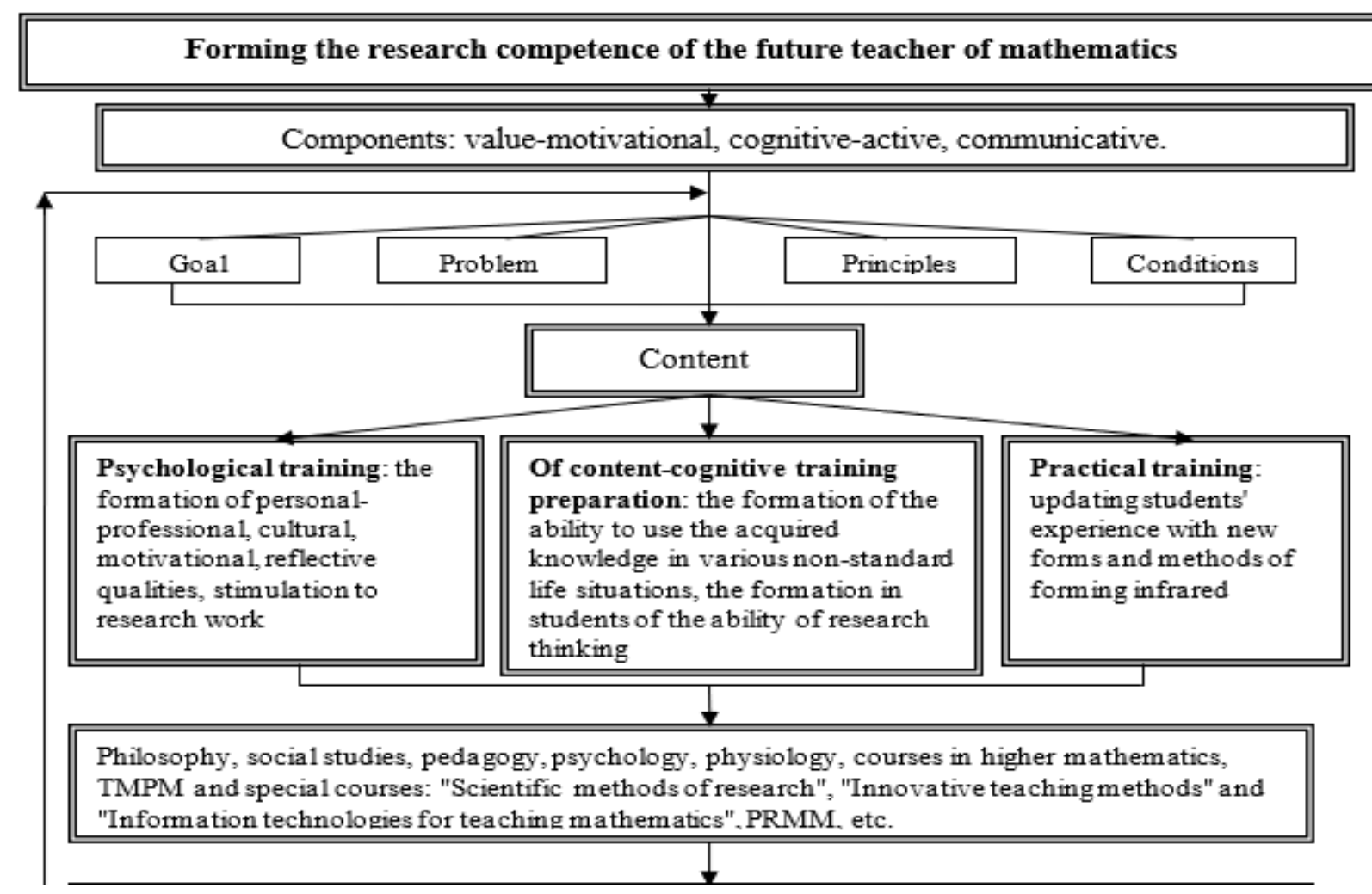


Forms: psychological and pedagogicaltrainings, problem lectures, discussions, talks, seminars, scientific and practicalconferences, term papers, practicalexercises in game and competitive form, pedagogical practice, production practice, graduation work

Methods: research methods, competence approach, activity approach, project method, interactive method, mathematicalmodeling, brainstorming, visual-active method, etc.

Means: educational-methodical complexes, textbooks, teaching aids, methodical recommendations, interactive whiteboard, didactic materials, electronic textbooks, mathematical models. computer. etc.

Technologies: developmentallearning, problematic, heuristic, project, programmed, healthpromoting, informationaleducation, etc.

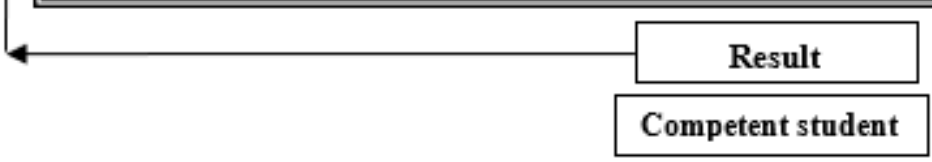

Figure 1: Model of formation of research competence of the future teacher of mathematics.

To effectively implement the model for the formation of the research competence of the future teacher of mathematics, the following pedagogical conditions are created:

- The presence of a graduate's competence model, which reflects its basic functions and competencies.

- Defining a specific learning objective.

- Identify specific ways to achieve the goal.

- Formulation of specific learning outcomes in the form of specific competences.

- The presence in the educational institution of an appropriate educational environment and qualified teachers in competence training.

- The content of education is focused on forming readiness of students studying mathematics to research activity and satisfies the reality principle aimed at the development of universal methods of cognitive activity;

- The organization of the educational process puts the student in the active position of the researcher, the acquisition of universal methods of cognitive activity, involves the critical analysis, selection and design of the personally significant content of research activity;

- The teacher conducts the management of research activities of students studying mathematics and psychological and pedagogical support, based on the preparedness of his preparedness for such work.

We used the following forms, tools, methods and technologies. Forms: psychological and pedagogical trainings, problem lectures, discussions, talks, seminars, scientific and practical conferences, coursework, practical classes in game and competition form, pedagogical practice, industrial practice, thesis. Means: textbooks, tutorials, methodical recommendations, computer, interactive whiteboard, ICT, didactic materials, educational programs, mathematical models. Methods: research methods, competence approach, activity approach, project method, interactive method, mathematical modeling, brainstorming, visual-active method, motivational methods of teaching mathematics. The basic technologies supporting the competence approach in training are: 
technology of problem training; project training; development of critical thinking; cognitive learning; training in the global information community.

\section{Conclusions and Recommendations}

Thus, a model has been developed for the formation of the research competence of the mathematics teacher, consisting of three main components: value-motivational, cognitive-activity, communicative. The model of the formation of the IR includes the purpose, objectives, principles, content of training, methods, tools, techniques, technologies and the following three preparations: psychological; of content-cognitive; practical.

The study specifies the pedagogical conditions necessary for the formation of research competence; the principles of forming the research competence of the mathematics teacher are defined; criteria are determined reflecting the level of the development of research competence. Formation of research competence of the teacher of mathematics was carried out through psychological; of content-cognitive; practical training. Specific features of the phased development of the properties of the research competence of the future teacher are determined.

\section{Appendices}

In the system of higher pedagogical education, psychological and pedagogical trainings, problem lectures, discussions, talks, seminars, scientific and practical conferences, term papers, practical exercises in game and competition form, pedagogical practice, industrial practice, graduate work. Research required the connection of the process of preparing future teachers with life and pedagogical practice. Therefore, they always acquainted students with the current state of school practice.

A systematic work was carried out to unite the psychological, of content-cognitive and practical training of future teachers. Students receive general information about the essence of research competence, systematize knowledge obtained in other subjects.

In pedagogical universities in the process of professional training of the teacher of mathematics the following types of search and independent work were used:

- scientific and methodical work of students;

- project implementation;

- drafting and solution of search problems;

- participation of students in scientific and practical conferences;

- game and search forms of employment, trainings;

- execution by students of course and diploma papers;

- Pedagogical and industrial practice of students.

In practice, students consolidate the knowledge gained in special courses, carry out project, course and diploma work with the help of a manager, develop skills necessary for search and independent work. At the last stage of the experimental work the students master the technologies of scientific research work. 
At the beginning and the end of the experimental experiment with the help of surveys and tests, the level of professional preparation of students for research work was studied, the results of which were presented in Table 1. The results obtained at each stage of the mathematics teacher's professional training process, by analyzing students' answers, and subject tests, independent work of students, were presented in Figure 2.

Table 1: level of professional training of the future teacher of mathematics

\begin{tabular}{|l|l|l|l|l|l|l|l|l|}
\hline \multirow{1}{*}{$\begin{array}{c}\text { Types of } \\
\text { training }\end{array}$} & \multicolumn{4}{|c|}{ Beginning of the experiment } & \multicolumn{3}{c|}{ The end of the experiment } \\
\cline { 2 - 9 } & $\begin{array}{c}\text { The experimental } \\
\text { group (EG) }\end{array}$ & \multicolumn{2}{c|}{$\begin{array}{c}\text { Control group } \\
\text { (CG) }\end{array}$} & \multicolumn{2}{c|}{$\begin{array}{c}\text { The experimental } \\
\text { group }\end{array}$} & \multicolumn{2}{c|}{ Control group } \\
\cline { 2 - 9 } & $\begin{array}{c}\text { number } \\
\text { of } \\
\text { students }\end{array}$ & $\begin{array}{c}\text { \% } \\
\text { qualities }\end{array}$ & $\begin{array}{c}\text { number } \\
\text { of } \\
\text { students }\end{array}$ & $\begin{array}{c}\text { \% } \\
\text { qualities }\end{array}$ & $\begin{array}{c}\text { number } \\
\text { of } \\
\text { students }\end{array}$ & $\begin{array}{c}\text { \% } \\
\text { qualities }\end{array}$ & $\begin{array}{c}\text { number } \\
\text { of } \\
\text { students }\end{array}$ & $\begin{array}{c}\text { \% } \\
\text { qualities }\end{array}$ \\
\hline Psychologists & 217 & 52,9 & 217 & 52,9 & 361 & 88 & 265 & 64,6 \\
\hline $\begin{array}{l}\text { Informative } \\
\text { and } \\
\text { informative }\end{array}$ & 289 & 70,48 & 289 & 70,48 & 361 & 88 & 241 & 58,78 \\
\hline Practitioners & 120 & 29,26 & 135 & 32,9 & 362 & 88,29 & 265 & 64,6 \\
\hline
\end{tabular}

In order to identify the level of professional preparedness of students in the formation of a component of research competence, a second survey was conducted. The results showed that the level of professional training of future teachers has increased. Analyzing the results obtained before and at the end of the experimental work on the quality of the level of professional training, we were convinced of the effectiveness of the model of the formation of research competence that we are creating. Increasing the level has led to the fact that students with internal needs have reached a high level. And students with a special education, not requiring constant selfimprovement, corresponded to a good and average level. To compare the level of professional training of the mathematics teacher before and after the experimental work, we give the following tables $2,3,4$.

Table 2: level of the formation of research competence of students (psychological component)

\begin{tabular}{|l|c|c|c|c|c|c|c|c|}
\hline \multirow{3}{*}{ Level } & \multicolumn{3}{|c|}{ Beginning of the experiment } & \multicolumn{3}{c|}{ The end of the experiment } \\
\cline { 2 - 9 } & \multicolumn{2}{|c|}{ EG } & \multicolumn{2}{c|}{ CG } & \multicolumn{2}{c|}{ EG } & \multicolumn{2}{c|}{ CG } \\
\cline { 2 - 10 } & $\begin{array}{c}\text { number of } \\
\text { students }\end{array}$ & $\%$ & $\begin{array}{c}\text { number of } \\
\text { students }\end{array}$ & $\%$ & $\begin{array}{c}\text { number of } \\
\text { students }\end{array}$ & $\%$ & $\begin{array}{c}\text { number of } \\
\text { students }\end{array}$ & $\%$ \\
\hline Highest & 48 & 11,707 & 48 & 11,707 & 120 & 29,4 & 48 & 11,7 \\
\hline Good & 169 & 41,219 & 169 & 41,219 & 241 & 58,8 & 217 & 52,9 \\
\hline Average & 193 & 47,073 & 193 & 47,073 & 49 & 11,8 & 145 & 35,3 \\
\hline
\end{tabular}

Table 3: The level of content-cognitive training of students

\begin{tabular}{|l|l|c|c|c|c|c|c|c|}
\hline \multirow{3}{*}{ Level } & \multicolumn{3}{|c|}{ Beginning of the experiment } & \multicolumn{3}{c|}{ The end of the experiment } \\
\cline { 2 - 9 } & \multicolumn{2}{|c|}{ EG } & \multicolumn{2}{c|}{ CG } & \multicolumn{2}{c|}{ EG } & \multicolumn{2}{c|}{ CG } \\
\cline { 2 - 10 } & $\begin{array}{c}\text { number of } \\
\text { students }\end{array}$ & $\%$ & $\begin{array}{c}\text { number of } \\
\text { students }\end{array}$ & $\%$ & $\begin{array}{c}\text { number of } \\
\text { students }\end{array}$ & \% & $\begin{array}{c}\text { number of } \\
\text { students }\end{array}$ & \% \\
\hline Highest & 48 & 11,7 & 48 & 11,7 & 120 & 29,4 & 48 & 11,7 \\
\hline Good & 145 & 35,4 & 145 & 35,4 & 241 & 58,8 & 193 & 47 \\
\hline Average & 217 & 52,9 & 217 & 52,9 & 49 & 11,8 & 169 & 41,3 \\
\hline
\end{tabular}


Table 4: levels of practical training of students

\begin{tabular}{|l|l|c|c|c|c|c|c|c|}
\hline \multirow{3}{*}{ Level } & \multicolumn{3}{|c|}{ Beginning of the experiment } & \multicolumn{3}{c|}{ The end of the experiment } \\
\cline { 2 - 10 } & \multicolumn{2}{|c|}{ EG } & \multicolumn{2}{c|}{ CG } & \multicolumn{2}{c|}{ EG } & \multicolumn{2}{c|}{ CG } \\
\cline { 2 - 10 } & $\begin{array}{c}\text { number of } \\
\text { students }\end{array}$ & $\%$ & $\begin{array}{c}\text { number of } \\
\text { students }\end{array}$ & $\%$ & $\begin{array}{c}\text { number of } \\
\text { students }\end{array}$ & $\%$ & $\begin{array}{c}\text { number of } \\
\text { students }\end{array}$ & \% \\
\hline Highest & 48 & 11,7 & 48 & 11,7 & 169 & 41,2 & 96 & 23,4 \\
\hline Good & 72 & 17,6 & 97 & 23,5 & 193 & 47 & 169 & 41,3 \\
\hline Average & 290 & 70,6 & 265 & 64,7 & 48 & 11,8 & 145 & 35,4 \\
\hline
\end{tabular}

Now, according to tables 2, 3, 4, we show the dynamics of changes in psychological, informative and practical training for the formation of research competence of future teachers in figures 3,4 , 5 .
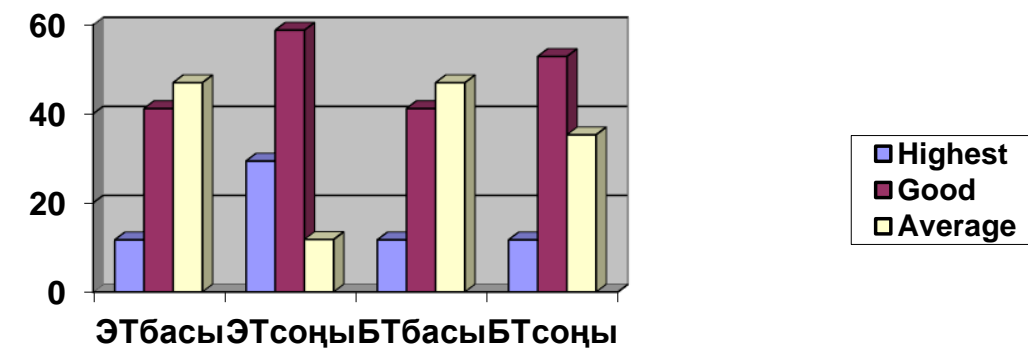

Figure 3: Dynamics of changes in the level of psychological training

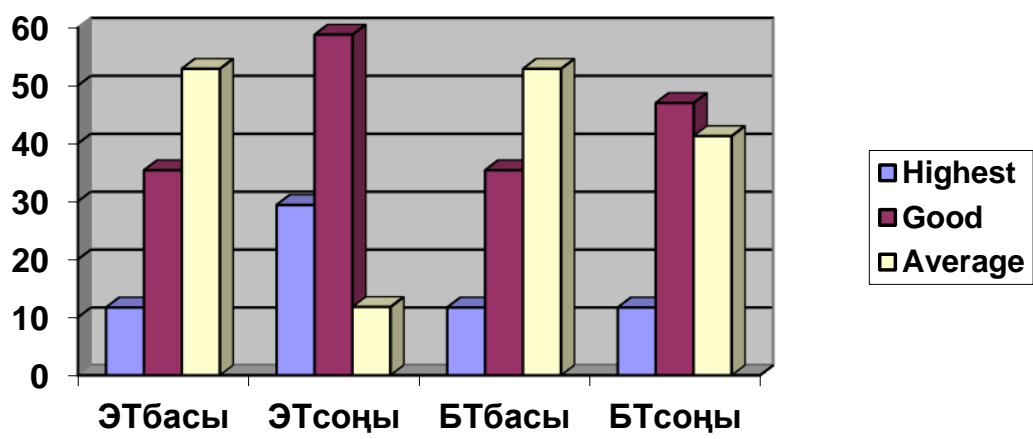

Figure 4: Dynamics of changes in the level of content and cognitive training

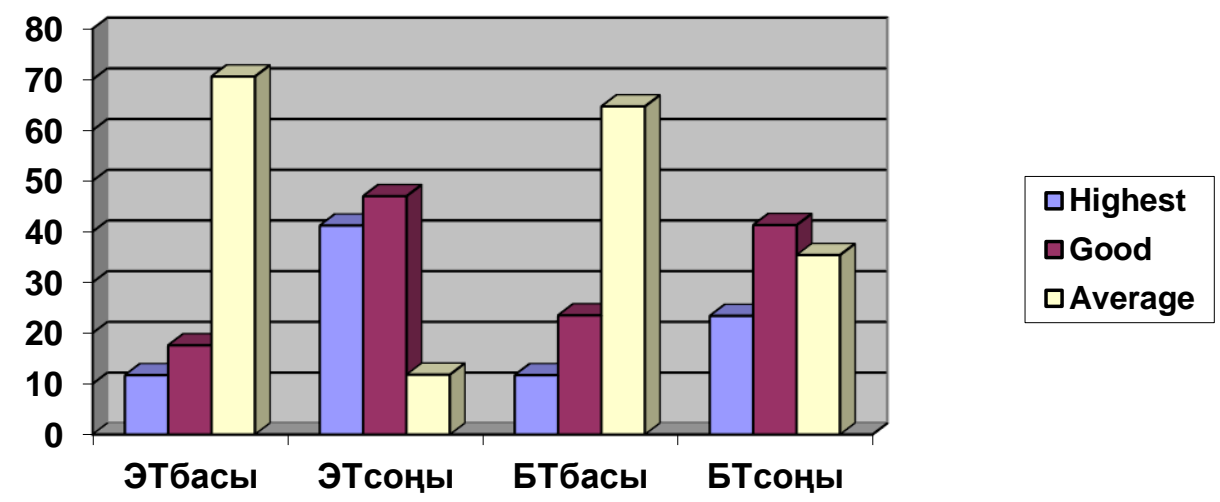

Figure 5: Dynamics of changes in the level of practical training 
Indicators of psychological, theoretical and practical training (in 5-point system) in experimental work are given in table 5.

Table 5: Dynamics of indicators of professional training in experimental work

\begin{tabular}{|c|c|c|c|c|c|c|c|c|}
\hline \multirow[t]{3}{*}{ Training record } & \multirow[t]{3}{*}{ Group } & \multirow[t]{3}{*}{$\mathbf{n}$} & \multicolumn{4}{|c|}{ Result } & \multirow[t]{3}{*}{$\mathbf{t}$} & \multirow[t]{3}{*}{$\mathbf{P}$} \\
\hline & & & \multicolumn{2}{|c|}{$\begin{array}{c}\text { Beginning of the } \\
\text { experiment }\end{array}$} & \multicolumn{2}{|c|}{$\begin{array}{c}\text { The end of the } \\
\text { experiment }\end{array}$} & & \\
\hline & & & $\bar{X}$ & Sx & $\bar{X}$ & Sx & & \\
\hline Psychologists & $\begin{array}{l}\text { Experimental } \\
\text { control }\end{array}$ & $\begin{array}{l}410 \\
410 \\
\end{array}$ & $\begin{array}{l}3,8 \\
3,7 \\
\end{array}$ & $\begin{array}{l}0,77 \\
0,76\end{array}$ & $\begin{array}{l}4,6 \\
3,9 \\
\end{array}$ & $\begin{array}{l}0,57 \\
0,68 \\
\end{array}$ & 0,2 & $<0,05$ \\
\hline $\begin{array}{l}\text { Informative and } \\
\text { informative }\end{array}$ & $\begin{array}{l}\text { Experimental } \\
\text { control }\end{array}$ & $\begin{array}{l}410 \\
410 \\
\end{array}$ & $\begin{array}{l}3,5 \\
3,5 \\
\end{array}$ & $\begin{array}{l}0,69 \\
0,69 \\
\end{array}$ & $\begin{array}{l}4,2 \\
3,7 \\
\end{array}$ & $\begin{array}{l}0,62 \\
0,66 \\
\end{array}$ & 3,3 & $<0,05$ \\
\hline Practitioners & $\begin{array}{l}\text { Experimental } \\
\text { control }\end{array}$ & $\begin{array}{l}410 \\
410 \\
\end{array}$ & $\begin{array}{l}3,40 \\
3,47 \\
\end{array}$ & $\begin{array}{l}0,69 \\
0,69 \\
\end{array}$ & $\begin{array}{l}4,29 \\
3,88 \\
\end{array}$ & $\begin{array}{l}0,66 \\
0,45 \\
\end{array}$ & 3 & $<0,05$ \\
\hline
\end{tabular}

Analysis of the dynamics of indicators of psychological training in experimental work.

In terms of growth, the indicator of the level of psychological preparation of the experimental group exceeds the indicator of the observation group. When checking the correctness of the discrepancy between the growth index, the student's t-test is used to compare the values obtained from the calculation with the critical values.

Indicators of psychological training at the beginning and end of the experiment are shown in table 6.

Table 6: Dynamics of indicators of psychological training

\begin{tabular}{|c|c|c|c|c|c|c|c|}
\hline \multirow[t]{3}{*}{ Group } & \multirow[t]{3}{*}{ n } & \multicolumn{4}{|c|}{ Result } & \multirow[t]{3}{*}{$\mathbf{t}$} & \multirow[t]{3}{*}{$\mathbf{P}$} \\
\hline & & \multicolumn{2}{|c|}{ Beginning of the experiment } & \multicolumn{2}{|c|}{ The end of the experiment } & & \\
\hline & & $X$ & $\mathbf{S}_{\mathrm{x}}$ & $X$ & $\mathbf{S}_{\mathbf{x}}$ & & \\
\hline Experimental & 410 & 3,8 & 0,77 & 4,6 & 0,57 & 0,8 & \\
\hline Control & 410 & 3,7 & 0,76 & 3,9 & 0,68 & 0,2 & $<0,05$ \\
\hline
\end{tabular}

The students of the experimental groups with the control groups (B. T.:3,9; $\mathrm{Sx}=0,68 ; \mathrm{V}=16 \%$ ) showed a high result (E. T.:4,6; $\mathrm{Sx}=0,57 ; \mathrm{V}=11 \%$ ). At $\mathrm{p}<0.05$, the growth of indicators of psychological preparation in the experimental group 0.8 ; in the control group 0.2 ..

Now we perform the calculation in the following sequence:

For each group $\left(\mathrm{X}_{1}\right.$ и $\left.\mathrm{X}_{2}\right)$ calculate the arithmetic mean (1), (2) and the variance $\left(S_{1}^{2}, S_{2}^{2}\right)$ by formulas (6), (7):

$$
\begin{aligned}
& \bar{X}_{1}=\frac{\sum X_{i}}{n}=\frac{340}{410}=0,8 \\
& \bar{X}_{1}=\frac{\sum X_{i}}{n}=\frac{90}{410}=0,2
\end{aligned}
$$


In terms of growth, the indicator of the level of psychological preparation of the experimental group exceeds the indicator of the control group. When checking the correctness of the discrepancy in the growth index, to compare the initial values with numerical values Student's t-criterion was used. Now we perform the calculation in the following sequence:

We find the sum of the squares of the growth of the experimental group results:

$\sum x_{1}^{2}=420$

We find the sum of the squares of growth of the results of the control group:

$\sum x_{1}^{2}=90$

We find the sum of the increase in the results of the experimental and control groups and square them:

$$
\begin{aligned}
& \sum x_{1}=115600 \\
& \sum x_{2}=8100
\end{aligned}
$$

We calculate the variance:

$$
S_{1}^{2}=\frac{n \sum x_{i}^{2}-\left(\sum x\right)^{2}}{n(n-1)}=\frac{410 \cdot 420-144400}{410(410-1)}=0,35
$$

$S_{2}^{2}=\frac{410 \cdot 90-8100}{410(410-1)}=0,18$

Check the assumption of equal variance by the F-criterion:

$S_{1}^{2}=S_{2}^{2}$

$F=\frac{S_{1}^{2}}{S_{2}^{2}}=\frac{0,35}{0,18}=1,95$

$\mathrm{F}_{\text {гр }}=2,21 ; 1,95<2,21$.

The value obtained is less than the table value, in which the zero assumption is not excluded. That is, the variances can be considered equal.

We calculate the standard error of the difference:

$$
S_{\bar{x}_{1}-\bar{x}_{2}}=\sqrt{\frac{S_{1}^{2}}{n_{1}}}+\frac{S_{2}^{2}}{n_{2}}=\sqrt{\frac{0,34}{410}+\frac{0,18}{410}}=3.5
$$

We compute the $\mathrm{t}$-criterion and compare the initial result with the tabulated value $(\mathrm{P}=0.05)$ in the ranked value level and the degree of freedom $-\mathrm{f}=\mathrm{n}_{1}+\mathrm{n}_{2}-2=410+410-2=818$.

$$
t=\frac{\bar{x}_{1}-\bar{x}_{2}}{S_{\bar{x}_{1}-\bar{x}_{2}}}=\frac{0,8-0,2}{3.5}=0.2
$$


The value found is 0.2 and at the level of $5 \%(\mathrm{P}<0.05)$ in the degrees of freedom 818 is 1.97 . From this, a reliable decision was made that the difference in sampling checks is statistically correct. Due to the fact that the results obtained in the calculation exceed the table, it can be concluded that the level of theoretical preparation of the experimental group exceeds the level of content-cognitive training in the control group.

Since the process of professional training in the experimental group was provided by a system of innovative methods and means, new pedagogical and information technologies, an electronic textbook, a methodology for forming the research competence of the future mathematics teacher. Analysis of the dynamics of indicators of content-cognitive training of students in experimental work.

Table-7 shows the indicators of content-cognitive training preparation at the beginning and end of the experiment.

Table 7: Dynamics of indicators of content-cognitive training preparation

\begin{tabular}{|c|c|c|c|c|c|c|c|}
\hline \multirow[t]{3}{*}{ Group } & \multirow[t]{3}{*}{ n } & \multicolumn{4}{|c|}{ Result } & \multirow[t]{3}{*}{$\mathbf{t}$} & \multirow[t]{3}{*}{$\mathbf{P}$} \\
\hline & & \multicolumn{2}{|c|}{ beginning of the experiment } & \multicolumn{2}{|c|}{ the end of the experiment } & & \\
\hline & & $\bar{X}$ & $\mathbf{S}_{\mathbf{x}}$ & $\bar{X}$ & $\mathbf{S}_{\mathbf{x}}$ & & \\
\hline experimental & 410 & 3,5 & 0,69 & 4,2 & 0,62 & 0,04 & $<0,05$ \\
\hline control & 410 & 3,5 & 0,69 & 3,7 & 0,66 & 3,3 & \\
\hline
\end{tabular}

For each group $\left(\mathrm{X}_{1}\right.$ и $\left.\mathrm{X}_{2}\right)$ calculate the arithmetic mean and variance $\left(S_{1}^{2}, S_{2}^{2}\right)$ :

$$
\begin{aligned}
& \bar{X}_{1}=\frac{\sum X_{i}}{n}=\frac{73}{410}=0,18 \\
& \bar{X}_{1}=\frac{\sum X_{i}}{n}=\frac{48}{410}=0,12
\end{aligned}
$$

We find the sum of the squares of the growth of the results of the experimental group: $\sum x_{1}^{2}=73$

We find the sum of squares of growth of the results of the control group: $\sum x_{1}^{2}=48$

We find the sum of the increase in the results of the experimental and control groups and square them:

$\sum x_{1}=5329$
$\sum x_{2}=2304$ 
Let us calculate the dispersions:

$$
\begin{aligned}
& S_{1}^{2}=\frac{n \sum x_{i}^{2}-\left(\sum x\right)^{2}}{n(n-1)}=\frac{410 \cdot 73-5329}{410(410-1)}=0,15 \\
& S_{2}^{2}=\frac{410 \cdot 48-2304}{410(410-1)}=0,10
\end{aligned}
$$

Check the assumption of equal variance by the F-criterion: $S_{1}^{2}=S_{2}^{2}$.

$$
F=\frac{S_{1}^{2}}{S_{2}^{2}}=\frac{0,15}{0,10}=1,5
$$

$F_{z p}=2,21 ; 1,5<2,21$.

The resulting value is less than the table value, in which the zero value does not exclude. That is, the variances can be considered equal.

Calculate the standard error of the difference (6):

$$
S_{\bar{x}_{1}-\bar{x}_{2}}=\sqrt{\frac{S_{1}^{2}}{n_{1}}}+\frac{S_{2}^{2}}{n_{2}}=\sqrt{\frac{0,15}{410}+\frac{0,10}{410}}=0,02
$$

Calculate the t-criterion and compare the original result with the table value of the degree of freedom in the selected value $(\mathrm{P}=0,05)$.

$f=n_{1}+n_{2}-2=410+410-2=818$.

$$
t=\frac{\bar{x}_{1}-\bar{x}_{2}}{S_{\bar{x}_{1}-\bar{x}_{2}}}=\frac{0,18-0,12}{0,02}=3
$$

The value found is 3 and is equal to 2.04 in the tabular 34 degree of freedom at the level of $5 \%$ of the value $(\mathrm{P}<0.05)$. The difference between the sample checks is statistically correct. Due to the fact that the results obtained in the calculation exceed the table, it can be concluded that the level of theoretical preparation of the experimental group exceeds the level of theoretical training in the control group.

Analysis of the dynamics of indicators of practical training of students in experimental work table8 shows the indicators of practical training at the beginning and end of the experiment. 
Table 8: Dynamics of indicators of practical training

\begin{tabular}{|c|c|c|c|c|c|c|c|}
\hline \multirow[t]{3}{*}{ Group } & \multirow[t]{3}{*}{$\mathbf{n}$} & \multicolumn{4}{|c|}{ Result } & \multirow[t]{3}{*}{$\mathbf{t}$} & \multirow[t]{3}{*}{$\mathbf{P}$} \\
\hline & & \multicolumn{2}{|c|}{ beginning of the experiment } & \multicolumn{2}{|c|}{ the end of the experiment } & & \\
\hline & & $\bar{X}$ & $\mathbf{S}_{\mathbf{x}}$ & $\bar{X}$ & $\mathbf{S}_{\mathbf{x}}$ & & \\
\hline experimental & 410 & 3,40 & 0,69 & 4,29 & 0,66 & & \\
\hline control & 410 & 3,47 & 0,69 & 3,88 & 0,45 & 11,7 & 0,03 \\
\hline
\end{tabular}

According to the growth rate, the indicator of the level of psychological preparation of the experimental group exceeds the indicator of the control group. When checking the correctness of the discrepancy in the growth rate, the Student's t-test was used to compare the values obtained as a result of the calculation with critical values. Now we perform the calculation in the following sequence:

For each group $\left(\mathrm{X}_{1}\right.$ и $\left.\mathrm{X}_{2}\right)$, we calculate the arithmetic mean of (5.4), (5.5) and the variance $\left(S_{1}^{2}, S_{2}^{2}\right)$ by formulas (6), (7)

$$
\begin{aligned}
& \bar{X}_{1}=\frac{\sum X_{i}}{n}=\frac{362}{410}=0,88 \\
& \bar{X}_{1}=\frac{\sum X_{i}}{n}=\frac{168}{410}=0,41
\end{aligned}
$$

In terms of growth, the indicator of the experimental group is higher than that of the control group. We find the sum of the squares of the growth of the results of the experimental group:

$\sum x_{1}^{2}=460$

We find the sum of squares of growth of the results of the control group:

$\sum x_{1}^{2}=168$

We find the sum of the increase in the results of the experimental and control groups and square them:

$\sum x_{1}=131044$

$\sum x_{2}=28224$

Let us calculate the dispersions:

$$
\begin{aligned}
& S_{1}^{2}=\frac{n \sum x_{i}^{2}-\left(\sum x\right)^{2}}{n(n-1)}=\frac{410 \cdot 460-131044}{410(410-1)}=0,34 \\
& S_{2}^{2}=\frac{410 \cdot 168-28224}{410(410-1)}=0,24
\end{aligned}
$$


F- we check the assumption that the variance is equal to the criterion:

$$
F=\frac{S_{1}^{2}}{S_{2}^{2}}=\frac{0,34}{0,24}=1,42
$$

$F_{z p}=2,21 ; 1,42<2,21$.

The obtained value is less than the table value, where the zero assumption does not exclude. That is, the variances can be considered equal.

We calculate the standard error of the difference:

$$
S_{\bar{x}_{1}-\bar{x}_{2}}=\sqrt{\frac{S_{1}^{2}}{n_{1}}}+\frac{S_{2}^{2}}{n_{2}}=\sqrt{\frac{0,34}{410}+\frac{0,24}{410}}=0,04
$$

We compute the criterion - $t$ and compare the outgoing result with the tabulated value in the selected level $(\mathrm{P}=0,05)$

$$
\begin{gathered}
f=n_{1}+n_{2}-2=410+410-2=818 . \\
t=\frac{\bar{x}_{1}-\bar{x}_{2}}{S_{\bar{x}_{1}-\bar{x}_{2}}}=\frac{0,88-0,41}{0,04}=11.75
\end{gathered}
$$

The value found is 11,75 at the level of $5 \%$ of the value $(\mathrm{P}<0.05)$ of the tabular 818 th degree of freedom is 1,97 . The difference between the sample checks is statistically correct. Due to the fact that the results obtained in the calculation exceed the table, it can be concluded that the level of theoretical preparation of the experimental group exceeds the level of theoretical training in the control group.

Thus, the system of methods and means of forming the research competence of the future teacher of mathematics presented in higher educational institutions demonstrates the real effectiveness of modern educational technologies and techniques.

Since the experimental group was provided with a methodology for developing research competence and innovative methods, tools, new pedagogical technologies

\section{References}

[1] A new dictionary of methodological terms and concepts. Available at https://methodological_terms.academic.ru/

[2] Baidenko V. I. Basic skills (key competences) as an integrating factor of the educational process. Moscow: Scientific and methodical collection, 2002.18.

[3] Choshanov M. A. Flexible technology of problem-modular training Text.: Method, manual. / M. A. Choshanov. Moscow: Public education, 1996.114.

[4] Competence in education: design experience [Text]: collection of scientific works / Under the editorship of A.V. Khutorskoy. Moscow: Scientific-innovation enterprise "INEC", 2007. 327. 
[5] Danilov M.A Theoretical foundations of education and the problem of education of cognitive activity and independence of students International Journal of education of cognitive activity and independence of schoolchildren. Kazan, 1972. 3-23.

[6] Derkach A.M. Competence approach in secondary vocational education: risks of training an incompetent specialist. Journal of education problems. 4, 2011.

[7] Elagina L. V. formation of the culture of professional activity of the future specialist on the basis of competence-based approach. The dissertation on competition of a scientific degree $\mathrm{Ph}$. $\mathrm{D}$. Chelyabinsk, 2009

[8] Golub L. A. Research activity and research competence as two categories of pedagogy. Part 1. The theoretical basis of the research. Izhevsk: Publishing house Institute of advanced training, 2008. 57.

[9] Ibragimov G. I. Quality of education in the professional school: issues of theory and technology. Kazan: Editorial and publishing center "School", 2007. 248.

[10] Kaskatayeva. B.R. The formation of the research competence of future teachers of mathematics. Astana: International Journal of pedagogy «Vestnik ENU named after L. N. Gumileva», 1(98), 2014. 79-83.

[11] Kaskatayeva. B.R. Pedagogical conditions for forming the research competency in future teachers of mathematics. Proceedings of the 7th International Scientific Conference "Rural Environment, Education, Personality -REEP 2014", 103-109. Available at http://llufb.llu.lv/conference/REEP/2014/Latvia-Univ-Agricult-REEP-2014proceedings.pdf （in Latvian)

[12] Kazakhstan needs a breakthrough in digitalization. Available at https://kapital.kz/gosudarstvo/55843/kazahstanu-neobhodim-ryvok-v-cifrovizacii.html

[13] Kuzmina, N. In. Professionalism of the teacher and the master of industrial training, Moscow, 1990. 135.

[14] Lazarev V. S. Project activities at school: unexploited opportunities. 2015. https://vo.hse.ru/data/2015/09/28/1073775194/Lasarev.pdf

[15] Lobova G. N. Bases of preparation of students for research activity. Moscow, 2000.

[16] Lukankin G. A. Scientific and methodical bases of professional training of the teacher of mathematics at pedagogical Institute: author's abstract of doctor of pedagogical Sciences. Leningrad, 1989. 59.

[17] Markova, A. K. Professionalism, competence, qualification. Psychological basis of professional activity, Moscow, 2007. 855.

[18] Mukasheva A. B., Kasen G. A. Trends in the development of higher education in Kazakhstan. Available at http://www.rusnauka.com/27_NNM_2011/Pedagogica/4_93587.doc.html

[19] Pedagogical encyclopedia. Vol.3. Moscow: Soviet encyclopedia, 1996. 879.

[20] Sergeev I. S. How to implement the competence approach in education, Teaching history and obshhestvenno-tion in school. 3, 2004. 29-39.

[21] Shadrikov V. D. Personal qualities of the teacher as components of professional competence, International Journal «Vestnik Yaroslavl state University». 1, 2006, 15-21.

[22] Slastenin V. A. Pedagogy: textbook for students of pedagogical educational institutions. Moscow: SHKOLA-Press, 1998. 512.

[23] State standard of post-graduate education of the Republic of Kazakhstan. (2011). Astana. Available at do.ektu.kz>laws/goso/17ru.pdf. (in Kazakhstan)

[24] The UNESCO reading materials. Available at http://www.unesco.org/new/ru/unesco/aboutus/who-we-are/introducing-unesco/

[25] The law of the Republic of Kazakhstan "On education" dated July 27, 2007 №319-III. Available at https://online.zakon.kz/Document/?doc_id=30118747\#pos=0;0

[26] The concept of the state youth policy of Kazakhstan until 2020 "Kazakhstan 2020: the way to the future". Available at 
https://tengrinews.kz/zakon/pravitelstvo_respubliki_kazahstan_premer_ministr_rk/hozyaystvenna ya_deyatelnost/id-P1300000191/

[27] The modern model of the Kazakhstan education. Available at https://ppt4web.ru/pedagogika/sovremennaja-model-kazakhstanskogo-obrazovanija.html

[28] The formation of professional competence of students of technical University in modern conditions: monograph L. K. Grebenkina, N.. Suvorov. Ryazan, 2012, 180.

[29] Verbickij A. A. Contextual learning in a competence-based approach. Journal "Higher education in Russia". 11, 2006, 39-46.

[30] Wikipedia. Available at https://dic.academic.ru/dic.nsf/ruwiki/641981

[31] Zeer, E. F. Modernization of professional education: Competence-based approach, Moscow: Psychological and social Institute, 2006, 216.

[32] Zimnya I. A. Competence of the person a new quality of result of education. Problems of education quality, vol. 1. Moscow: 2003, 66[1] A new dictionary of methodological terms and concepts. Available at https://methodological_terms.academic.ru/

\footnotetext{
*Corresponding author.

E-mail address: Kaskataeva@ yandex.ru
} 